João B. Calixto

Maria M. Campos ${ }^{1}$

Michel F. Otuki ${ }^{1}$

Adair R.S. Santos ${ }^{2}$

\title{
Anti-Inflammatory Compounds of Plant Origin. Part II. Modulation of Pro-Inflammatory Cytokines, Chemokines and Adhesion Molecules
}

\begin{abstract}
It has been widely shown that many plant-derived compounds present significant anti-inflammatory effects. For this reason, they represent potential molecules for the development of new drugs, especially designed for the treatment and/or control of chronic inflammatory states such as rheumatism, asthma, inflammatory bowel diseases, atherosclerosis, etc. This review focuses on the naturally-occurring compounds with anti-inflammatory properties and attempts to correlate their actions with the modulation of cytokines and associated intracellular signalling pathways; it continues the review published in the November, 2003 issue of Planta Medica.
\end{abstract}

\section{Key words}

Medicinal plants · plant constituents · inflammation · cytokines · chemokines adhesion molecules

\section{Abbreviations}

\section{AP-1:}

activator protein-1

CCR1: $\quad$ chemokine receptor 1

CINC-1: cytokine-induced neutrophil chemoattractant 1

COX:
EGCG:

ELAM-1:

ERK:

GRO:

HUVEC:

ICAM-1:

IFN:

IL:

iNOS:

IRA:

JAK:

JNK:

LPS:

MAPK:

MCP:

MHC:

MIP:

MMP:

MPO:

$\mathrm{NF}-\kappa \mathrm{B}$

NO:

PAF:

PGEE:

PK:

\section{(-)-epigallocatechin gallate}

endothelial-leukocyte adhesion molecule-1 extracellular signal-regulated kinase growth-related oncogene human umbilical vein endothelial cells intercellular adhesion molecule-1 interferon interleukin inducible nitric oxide synthase the natural interleukin receptor activation janus kinase c-Jun NH2-terminal kinase lipopolysaccharide mitogen-activated protein kinases monocyte chemotactic protein major histocompatibility complex macrophage inflammatory protein matrix metalloproteinases myeloperoxidase nuclear factor kappa B nitric oxide platelet aggregation factor prostaglandin protein kinase

Affiliation

${ }^{1}$ Department of Pharmacology, CCB, Universidade Federal de Santa Catarina (UFSC), Florianópolis, SC, Brazil

${ }^{2}$ Department of Physiologic Sciences, CCB, Universidade Federal de Santa Catarina (UFSC), Florianópolis, SC, Brazil

Correspondence João B. Calixto · Department of Pharmacology · UFSC · Rua Ferreira Lima 82 · 88015-420, Florianópolis, SC . Brazil $\cdot$ Phone: +55-48-3319491 Fax: +55-48-2224164 . E-mail: calixto@farmaco.ufsc.br or calixto3@terra.com.br Note
Part 1: Planta Med 2003;69:973-983

Michel F. Otuki is a PhD student in Pharmacology and he thanks CNPq for scholarship support. Maria M. Campos holds a post-doctoral fellowship from Coordenação de Aperfeiçoamento de Pessoal de Nível Superior (CAPES). The studies from our group were supported by the Conselho Nacional de Desenvolvimento Científico e Tecnológico (CNPq), Financiadora de Estudos e Projetos (FINEP) and by Programa de Apoio aos Grupos de Excelência (PRONEX), Brazil

Received August 18, $2003 \cdot$ Accepted October 18, 2003 
PMA/TPA: phorbol myristate acetate

RANTES: regulated upon activation normal T-cell expressed and secreted

TGF- $\beta$ : $\quad$ transforming growth factor- $\beta$
TNF $\alpha$ : tumour necrosis factor

VCAM-1: vascular cell adhesion molecule-1

\section{Introduction}

The inflammatory process may be defined as a sequence of events that occurs in response to noxious stimuli, trauma or infection. These responses are orchestrated by a highly modulated interaction between mediators of inflammation and inflammatory cells [1]. Cytokines represent a group of multifunctional substances that are involved in many steps of the inflammatory response. Until now, more than 100 members of the cytokine family and their specific receptors have been identified [2], [3], [4]. Generally, cytokines can be classified as pro- or anti-inflammatory, depending on the way they influence inflammation. In a more simplified view, pro-inflammatory cytokines (e.g., IL-1 $\beta$, TNF $\alpha$, IL-6 and IL-18) seem to be involved in the initiation and amplification of the inflammatory process, whereas the anti-inflammatory cytokines (e.g., IL-10, TGF- $\beta$ and IRA) negatively modulate these events [5], [6].

Cytokines are produced by both resident and migrating cells, such as mast cells, macrophages and neutrophils and, after release; they can act either locally or systemically. Due to their redundant and pleiotropic actions, cytokines form a network in which one cytokine can induce its own production or even the secondary generation of other cytokines. In addition, it has been widely shown that most cytokine actions involve the activation of transcription factors (e.g., NF- $\mathrm{BB}$ and AP-1) and protein kinases (e.g., MAPK and PKC) that, in turn, regulate the expression of many target genes indispensable to the maintenance of the inflammatory state [3], [7]. For instance, cytokines may be responsible for the induction of several enzymes (e.g., iNOS and COX-2), receptors (PAF receptor, IL-2 receptor) and adhesion molecules (E-selectin, $\alpha$ - and $\beta$-integrins, ICAM-1, VCAM-1) [3], [8], [9].

A distinct group of cytokines, denoted chemokines (including IL-8, eotaxin, GRO, CINC-1 and RANTES) have the ability to chemoattract and activate leukocytes at the site of inflammation [10], [11]. Chemokine effects are mediated via interaction with $G$ protein-coupled receptors. Binding of chemokines to their specific receptors allows rolling leukocytes to become firmly adherent and able to transmigrate to the target tissue, a process largely dependent on the activation of adhesion molecules, mainly integrins [10], [12].

Recent evidence has indicated that cytokines (and chemokines), as well as their receptors, are involved in the pathophysiology of many inflammatory diseases, including sepsis, rheumatoid arthritis, atherosclerosis and asthma. These pathological states seem to be linked to an imbalance of the cytokine network and to the excessive recruitment of leukocytes to the inflammatory sites [3], [13], [15]. Because of this, the cytokine system constitutes a very interesting and promising target for the development of clinically relevant anti-inflammatory drugs. In fact, some specific cytokine modulators have been introduced into clinical practice during the last few years. Despite the effectiveness described for these drugs, their use is associated with some side effects [15], [16], [17] and, most important, with high cost. In this context, the identification of small molecule plant-derived compounds able to selectively interfere with the production and/or function of cytokines would constitute an important alternative for the treatment of many inflammatory diseases.

In the second part of this review we will focus on the recent contributions to the identification of naturally-occurring compounds derived from plants as potential modulators of the cytokine network and related cell migration process.

\section{Phenolic Compounds}

A substantial body of evidence obtained from both in vivo and in vitro studies supports the concept that various plant-derived compounds with anti-inflammatory properties exert their effects through the modulation of the cytokine system (for recent review see [18]). For instance, flavonoids, a class of compounds widely distributed throughout the plant kingdom, possess interesting anti-inflammatory actions [19], [20], [21]. Very recently, Xagorari et al. [22] have reported that luteolin (1) ( $\left.\mathrm{IC}_{50}<1 \mu \mathrm{M}\right)$, quercetin (2) ( $\mathrm{IC}_{50} 1 \mu \mathrm{M}$ ), luteolin 7-glucoside (approximate $\mathrm{IC}_{50}$ $50 \mu \mathrm{M})$ and the isoflavonoid genistein $\left(\mathrm{IC}_{50} 5 \mu \mathrm{M}\right)(3)$ inhibited LPS-stimulated TNF $\alpha$ and interleukin-6 release in RAW 264.7 macrophages, whereas eriodictyol and hesperetin only inhibited $\mathrm{TNF} \alpha$ release (approximate $\mathrm{IC}_{50}$ value of $50 \mu \mathrm{M}$ ). Luteolin also inhibited the production of TNF $\alpha$ in vivo and was capable of decreasing both PMA and oxazolone-induced allergic ear oedema [23]. Luteolin significantly reduced LPS-stimulated ICAM-1 expression in the liver of LPS (Salmonella enteriditis)-treated mice [24]. In a recent study, Das et al. [25] demonstrated that chronic administration of luteolin significantly attenuated ovalbumininduced airway bronchoconstriction and bronchial hyperreactivity. Moreover, the same treatment with luteolin was capable of reducing the levels of both IL- 4 and IL-5, whereas it induced an increase in IFN $\gamma$ in the broncheoalveolar lavage fluid of sensitised mice [25]. These authors have suggested that luteolin could be used as a lead molecule to identify effective therapies for the treatment of asthma.

Manna et al. [26] demonstrated that silymarin, a mixture of bioactive flavonoids isolated from Silybum marianum L. (Asteraceae) was able to prevent, in a concentration-dependent manner, $\mathrm{TNF} \alpha$-induced NF- $\kappa \mathrm{B}$ activation in human histiocytic lymphoma U-937 cells. Johnson et al. [27] also reported the effects of silymarin on the thymic lymphocyte population in mice. Intraperitoneal administration of silymarin ( 10 to $250 \mathrm{mg} / \mathrm{kg}$, once a day, for five days) resulted in the augmentation of CD4+ and CD8+ thymic lymphocyte populations, by a mechanism involving an increase in c-myc expression. In addition, silymarin significantly 
decreased the expression of IL-2 and IL-4, without affecting MHC II expression in mouse lymphocytes [27].

It has been demonstrated that a citrus polymethoxyflavonoid, nobiletin (4) (5,6,7,8,3',4'-hexamethoxyflavone) effectively inhibits the production of $\mathrm{PGE}_{2}$ and proMMP-9 in rabbit synovial fibroblasts [28]. More recently, Lin et al. [29] have shown that nobiletin $\left(\mathrm{IC}_{50}<4 \mu \mathrm{M}\right)$ suppressed IL-1 $\beta$-induced production of $\mathrm{PGE}_{2}$ in human synovial fibroblasts cells and decreased the expression of IL- $1 \alpha$, IL- $1 \beta$, TNF $\alpha$ and IL-6 mRNAs in J774A.1 macrophages (at a concentration of $32 \mu \mathrm{M}$ ) [29]. These results allow the authors to suggest that nobiletin could be a candidate for the development of a novel anti-inflammatory or immunomodulatory drug.

Baicalin (5), baicalein (6) and wogonin (7) are flavonoids present in Scutellaria baicalensis Georgi (Lamiaceae), a plant used in the treatment of a variety of inflammatory diseases such as bronchitis, nephritis, hepatitis, asthma, and atopic dermatitis [30]. The anti-inflammatory activities of these flavonoids have been attributed to their antioxidant properties and to their ability to inhibit LPS-induced NO production and iNOS gene expression, as well as the increase in TNF $\alpha$ levels by RAW 264.7 cells [31], [32]. Li et al. [33] have demonstrated that baicalin ( $\mathrm{IC}_{50}$ values ranging from 15 to $320 \mu \mathrm{g} / \mathrm{mL}$ ) and, to a lesser extent, baicalein, significantly inhibited the binding of several chemokines such as CXC, [stromal cell-derived factor (SDF)- $1 \alpha$ and IL-8], CC [macrophage inflammatory protein (MIP)- $1 \beta$, monocyte chemotactic protein (MCP)-2), and C lymphotactin (Ltn)] to human leukocytes or cells transfected with chemokine receptors. Baicalein also prevented eotaxin production (approximate $\mathrm{IC}_{50}$ value of $1.8 \mu \mathrm{g} / \mathrm{mL}$ ) and the mRNA eotaxin expression in human fibroblasts stimulated with IL-4 plus TNF $\alpha$ [34]. Confirming the in vitro studies, the coinjection of baicalein with interleukin-8 (IL-8) significantly inhibited IL-8-elicited neutrophil infiltration in rat skin. However, baicalin failed to block CX3C chemokine fractalkine/neurotactin or other cytokines, such as TNF $\alpha$ or IFN- $\gamma$ [33]. Several studies have demonstrated that most flavonoids, including baicalein ( $\mathrm{IC}_{50}$ values ranging from 2.4 to $9.7 \mu \mathrm{M}$ ) inhibit IL- $1 \beta-$, TNF $\alpha-$ and thrombin-induced endothelial leukocyte adhesion molecule-1 (ELAM-1) and ICAM-1 expression in cultured human umbilical vein endothelial cells (HUVEC) [19], [35]. Sartor et al. [36] have reported that different flavonoids ( IC $_{50}$ values between 0.4 and $450 \mu \mathrm{M}$ ), such as flavones (baicalein), anthocyanidins (delphinidin and pelargonidin), flavanols [epigallocatechin-3gallate (8)], flavonols [morin (9) and quercetin] and other compounds with antioxidant properties were highly effective in inhibiting the activities of leukocyte elastase, MMP-2 and MMP-9. Such actions might explain the anti-inflammatory, antiangiogenic, anti-invasive and antimetastatic properties described for these compounds. Krakauer et al. [37] have shown that baicalin ( $\mathrm{IC}_{50}$ values ranging from 3 to $50 \mu \mathrm{g} / \mathrm{mL}$ ) inhibited the expression and production of IL- $1 \beta$, IL-6, TNF $\alpha$, IFN $\gamma$, MIP- $1 \alpha / \beta$ in human peripheral blood mononuclear cells under stimulation with superantigenic staphylococcal exotoxins. More recently, Shen et al. [38] reported that baicalein and baicalin were able to decrease fMLP- or PMA-induced accumulation of reactive oxygen intermediates in human neutrophils and monocytes ( $\mathrm{IC}_{50}$ values ranging from 1.5 to $64.5 \mu \mathrm{M}$ ). Furthermore, baicalein and baicalin diminished the fMLP-induced increase in surface expression of

\section{Phenolic Compounds I:}
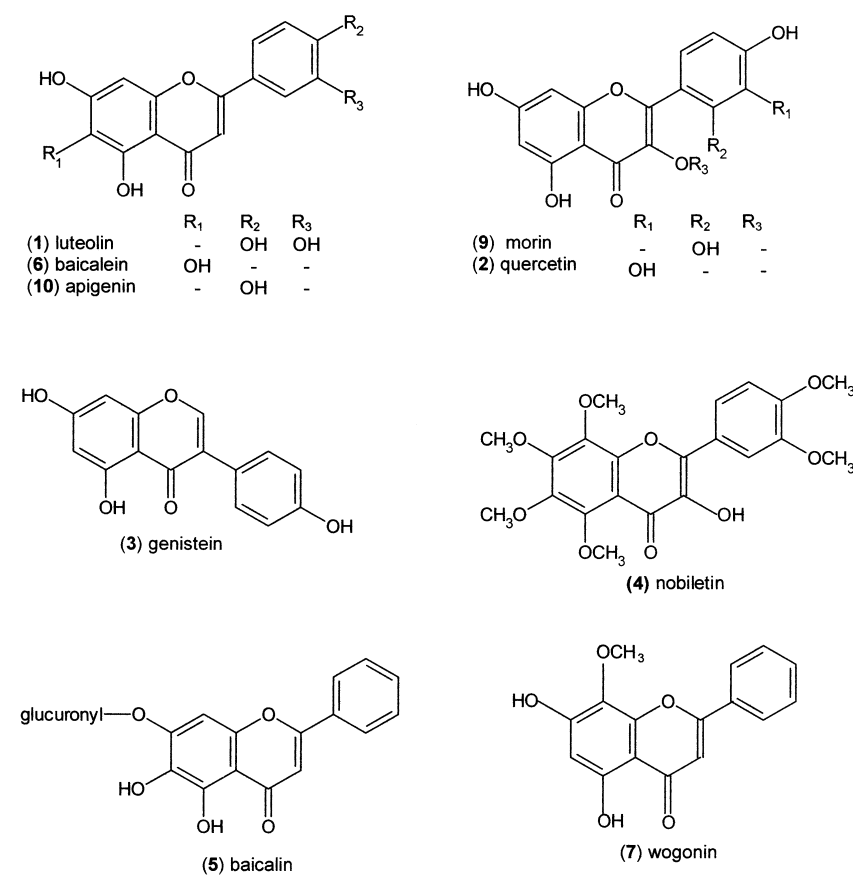

the integrin MAC-1 (CD11b/CD18) and MAC-1-dependent neutrophil adhesion [38]. Baicalein and wogonin (approximate $\mathrm{IC}_{50}$ values of 1 to $40 \mu \mathrm{M}$ ) were also effective in blocking the production and expression of IL- 6 and IL-8 in a human retinal pigment epithelial cell line [39].

It has been recently reported that standardised extracts of Ginkgo biloba L. ( IC $_{50}>400 \mu \mathrm{g} / \mathrm{mL}$ ) (Ginkgoaceae) (EGb 761) and its flavonoid component quercetin ( $\mathrm{IC}_{50}<200 \mu \mathrm{g} / \mathrm{mL}$ ) inhibited TNF $\alpha$ secretion in LPS-stimulated RAW 264.7 macrophages, by interfering with the phosphorylation and activation of JNK/SAPK and its downstream substrates c-Jun and ATF-2, and ERK1/2 and p38 MAPK. In addition, Wadsworth et al. [40] have shown that Ginkgo biloba extract (EGb 761) and quercetin suppress the activation of the transcription factor AP-1. Quercetin $\left(\mathrm{IC}_{50}<20 \mu \mathrm{M}\right.$ ) [41] and quercetin 3-O-methyl ether from Rhamnus nakaharai Hayata (Rhamnaceae) [42], as well as amoradicin ( IC $_{50} 28.5 \mu \mathrm{M}$ ) isolated from Amorpha fruticosa L. (Fabaceae) [43], markedly inhibited the production of TNF $\alpha$ in LPS-stimulated murine macrophages. Quercetin 3-O-methyl ether also caused a pronounced inhibition of TNF $\alpha$ formation according to an evaluation in LPS/ IFN- $\gamma$-stimulated murine microglial $\mathrm{N} 9$ cells [42]. Luteolin 4'-Oglucopyranoside, cosmosiin, apigenin (10), luteolin, quercimeritrin and kaempferol, from Kummerowia striata Thumb. (Leguminosae) exhibited concentration-dependent inhibitory effects on IL-5 bioactivity, with mean IC $_{50}$ values of 3.7, 14.2, 16.4, 18.7, 27.3 and $30.0 \mu \mathrm{M}$, respectively [44].

Okabe et al. [45] reported that (-)-epigallocatechin gallate (EGCG), the main constituent of green tea polyphenols, tannins [geraniin (11) and corilagin (12)] and the aqueous extract of leaves of Acer nikoense Maxim. (Aceraceae), a Japanese herbal medicine used for eye and liver diseases, effectively prevented TNF $\alpha$ release in BALB/3T3 cells stimulated with okadaic acid. The mean $\mathrm{IC}_{50}$ values obtained were $26 \mu \mathrm{M}$ for EGCG, $43 \mu \mathrm{M}$ for 
Phenolic Compounds II:

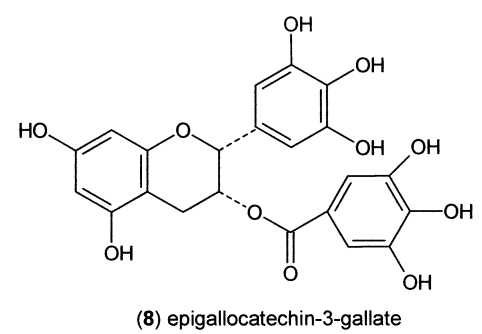<smiles></smiles>

(13) hypericin<smiles>COc1ccc(C(C)=O)c(O)c1</smiles><smiles>O=C1c2c(O)cc(O)cc2O[C@H](c2ccc(O)c(O)c2)[C@@H]1O</smiles>

(15) taxifolin<smiles>Oc1ccc(/C=C/c2cc(O)cc(O)c2)cc1</smiles>

geraniin, and $76 \mu \mathrm{M}$ for corilagin. In addition, treatment of animals with geraniin ( $5 \mathrm{mg} / \mathrm{site}$ ) and EGCG reduced the percentage of tumour-bearing mice from 80 to $40 \%$ and 73 to $0 \%$, and the average number of tumours from 3.8 to 1.1 and 4.2 to 0 , following topical application of 7,12-dimethylbenz[a]anthracene (DMBA) plus okadaic acid, respectively [45].

1,7-Bis(4-hydroxyphenyl)-1,4,6-heptatrien-3-one and procurcumenol present in the rhizomes of the plant Curcuma zedoaria L. (Zingiberaceae) were found to be effective in reducing the production of TNF $\alpha$ in LPS-activated macrophages, with mean $\mathrm{IC}_{50}$ values of $12.3 \mu \mathrm{M}$ and $310.5 \mu \mathrm{M}$, respectively [46]. Kang et al. [47] reported that hypericin (13), an active component of Hypericum perforatum L. (Hypericaceae), significantly inhibited

\section{Phenolic Compounds III:}
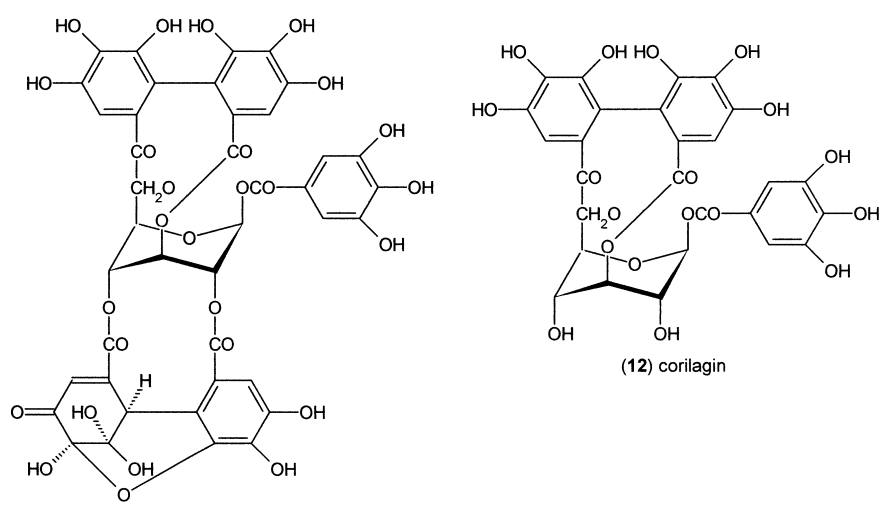

(11) geraniin

in a concentration-dependent manner IL-12 production in LPSactivated macrophages ( $\mathrm{IC}_{50} 1.45 \mu \mathrm{g} / \mathrm{mL}$ ). Hypericin potently inhibited the activation of the IL-12 gene promoter, suggesting that hypericin negatively regulated IL-12 production at the transcription level. Furthermore, Bork et al. [48] have demonstrated that hypericin inhibits PMA- and TNF $\alpha$-induced activation of NF$\kappa \mathrm{B}$ by a mechanism not involving antioxidant pathways. These results might explain some known biological activities of hypericin, including its reported antirheumatic effects [48].

It has been demonstrated that a methanolic extract of the root cortex of Paeonia suffruticosa Andrews (Ranunculaceae), known as mudanpi, inhibited in a concentration-related manner the secretion of IL- 8 and MCP-1 induced by PMA in human monocytic U937 cells (approximate $\mathrm{IC}_{50}$ value of $35 \mu \mathrm{g} / \mathrm{mL}$ ) [49]. Chou [50] demonstrated that its main active compound paeonol ( 2 '-hydroxy-4'-methoxyacetophenone) (14), exhibited analgesic and antiinflammatory effects in the rat model of carrageenan-evoked thermal hyperalgesia. The analgesic and anti-inflammatory effects of paeonol are associated with its ability to inhibit in a concentration-dependent manner the formation of several pro-inflammatory cytokines (such as TNF $\alpha$, IL-1- $\beta$ and IL-6), as well as the over-production of $\mathrm{NO}$ and $\mathrm{PGE}_{2}$. In addition, the effects of paeonol are also associated with an increase in the anti-inflammatory cytokine IL-10, with inhibition of neutrophil infiltration and iNOS and COX-2 protein expression [50]. Thus, paeonol represents a potential candidate for the development of a new anti-inflammatory therapy.

Pycnogenol, a compound isolated from the bark of Pinus maritime Mill (Pinaceae) exhibited a marked scavenger activity when evaluated in the murine macrophage cell lines RAW 264.7 and IC-21 stimulated with $\mathrm{H}_{2} \mathrm{O}_{2}$ and PMA, respectively. Furthermore, pycnogenol was found to be effective in reducing both the production of IL- $1 \beta$ and the expression of IL- $1 \beta$ mRNA in LPS-stimulated RAW 264.7 cells, an effect dependent on interference with the transcription factors NF- $\kappa$ B and AP-1 [51]. Recently, Bito et al. [52] have shown that taxifolin (15) purified from pycnogenol reduced IFN- $\gamma$-induced ICAM-1 protein, as well as mRNA expression in human keratinocytes, by affecting the activation of the transcription factor STAT-1 and the protein tyrosine phosphorylation of Janus kinase (JAK)-1. This suggests that the JAK-STAT pathway might be the molecular site of action of taxifolin [52].

Manthey et al. [53] have shown that the polymethoxylated flavone, 3,5,6,7,8,3',4'-heptamethoxyflavone ( IC $_{50} 5 \mu \mathrm{M}$ ) inhibits LPS-induced expression and the production of TNF $\alpha$, the chemokine MIP- $1 \alpha$ and IL-10 in monocytes. The polymethoxylated flavone has been reported to inhibit human phosphodiesterase activity and has been shown to induce a great elevation of cAMP levels in monocytes [53]. Other preliminary studies have reported that different classes of naturally occurring substances, such as stilbenes isolated from Magnoliae fargesii Cheng (Magnoliaceae) produced a marked inhibition of the expression of ICAM-1 and VCAM-1 on the surface of THP-1 human monocytes [54], [55], [56]. Stilbenes, such as 3,5-dihydroxy-4'-methoxystilbene and 2,3,4',5-tetrahydroxystilbene 2-O- $\beta$-D-glucopyranoside [as well as resveratrol (16)] were also effective in blocking TNF $\alpha$-induced cell-cell adhesion between HUVECs and THP-1 cells [55]. Diarylheptanoids, such as 1-(3,5-dimethoxy-4-hydroxyphenyl)- 
7-phenylhept-1-en-3-one (YPE-01), yakuchinone B and demethylyakuchinone $\mathrm{B}$, reduced the adhesion of both the human monocytic cell line U937 and the human eosinophilic cell line EoL- 1 to TNF $\alpha$-treated HUVECs ( IC $_{50}$ values ranging from 29 to $67.2 \mu \mathrm{M}$ ) [57]. In addition, these compounds were also effective in suppressing both IL- $1 \beta$ - and TNF $\alpha$-induced expression of E-selectin, VCAM-1 and ICAM-1 on the surface of the endothelial cells ( $\mathrm{IC}_{50}$ values ranging from 17.8 to $40.3 \mu \mathrm{M}$ ). Since YPE-01 reduces both VCAM-1 and ICAM-1 mRNA induction in TNF $\alpha$-stimulated endothelial cells, the authors suggest that this compound suppresses adhesion molecule expression at the transcriptional level. Furthermore, YPE-01 given systemically suppressed TPAinduced ear oedema in mice [57].

Piceatannol, another phenolic compound known as a selective inhibitor of the Syk tyrosine kinase significantly prevented $\mathrm{TNF} \alpha$-induced NF- $\kappa \mathrm{B}$ activation in lymphocytes and epithelial cells [58]. Some preliminary studies have indicated that other naturally occurring substances, such as the polyphenol chlorogenic acid, inhibit staphylococcal exotoxin-induced T cell proliferation (by $98 \%$ ) and the production of IL- $1 \beta$, TNF $\alpha$, IL-6, INF- $\gamma$, MCP-1, MIP- $1 \alpha$ and MIP- $1 \beta$ by human peripheral mononuclear cells [59]. Reynosin exhibited a concentration-dependent inhibition of CINC-1 induction in LPS-stimulated NRK-52E rat kidney epithelioid cells with a mean $\mathrm{IC}_{50}$ value of $1 \mu \mathrm{M}$ [60].

Tsuda et al. [61] reported that oral administration of a typical anthocyanin, cyanidin 3-O- $\beta$-D-glucoside, suppressed the zymosan-induced inflammatory response in rats. Treatment of cyanidin 3-O- $\beta$-D-glucoside also reduced the elevation of $\mathrm{NO}_{\mathrm{x}}$, TNF $\alpha$, IL-1 $\beta$, IL-6 and CINC-1 concentrations. Furthermore, cyanidin 3$O-\beta$-d-glucoside normalised the levels of several acute phase proteins, including $\alpha_{2}$-macroglobulin, albumin and transferrin in the serum of rats treated with zymosan [61]. It has been recently demonstrated that phoroglucinol derivatives, purified from Mallotus japonicus Mueller Arg. (Euphorbiaceae) [e.g., isomallotochromanol (17) and isomallotochromene (18)] are effective in inhibiting the mRNA expression and production of TNFo or IL-6 in RAW 264.7 cells ( IC $_{50}$ values ranging between 0.7 and $30 \mu \mathrm{M})$. These compounds also reduced the formation of TNF $\alpha$ and IL- 6 by human blood monocytes activated with LPS, with $\mathrm{IC}_{50}$ values ranging over a similar interval [62]. The effects described for these compounds seem to be dependent on the blockade of NF- $\kappa \mathrm{B}$ activation, but might also include the inhibition of other pro-inflammatory pathways.

Among the polyphenols, the compound obtained from the rhizome of Curcuma longa L. (Zingiberaceae), curcumin (19), presents high interest as a lead compound to develop new clinically relevant anti-inflammatory drugs. Apart from its effect on inflammatory events (for review, see [63]) this compound significantly blocked IL-12 mediated $\mathrm{T}$ cell proliferation and $\mathrm{Th}_{1}$ differentiation, an action that possibly implies its ability to reduce the production of pro-inflammatory cytokines [64]. Curcumin was found to significantly down-regulate the TNF $\alpha$-induced increase in MMP-13 mRNA and protein expression in primary human chondrocytes and SW1353 cells by a mechanism involving the inhibition of NF- $\kappa \mathrm{B}, \mathrm{c}-\mathrm{jun}$ and JNK [65]. Moreover, curcumin significantly inhibited the increase of both IL-1 $\beta$ and TNF $\alpha$ in a chronic model of inflammation in rats [66]. On account of these
Phenolic Compounds IV<smiles>COc1c(C)c(O)c(C(C)=O)c(O)c1Cc1c(O)c(C(C)=O)c(O)c2c1OC(C)(C)[C@H](O)C2</smiles><smiles>COc1c(C)c(O)c(C(C)=O)c(O)c1Cc1c(O)c(C(C)=O)c(O)c2c1OC(C)(C)C=C2</smiles><smiles>COc1cc(/C=C/C2=COCC(/C=C/c3ccc(O)c(OC)c3)=C2)ccc1O</smiles><smiles>O=C1C=C2CC3(O)COc4c(ccc(O)c4O)C3=C2C=C1O</smiles>

(20) hematein

characteristics, curcumin has been submitted to clinical trials. According to a recent evaluation [67], curcumin has been shown to be safe in six human trials designed to test its anti-inflammatory activities. Due to its anti-inflammatory properties, the clinical potential of curcumin for prevention and treatment of cancer was also assessed [68], [69].

Hematein (20) is a compound isolated from Caesalpinia sappan Linn (Leguminosae), a plant employed in oriental medicine as an analgesic or anti-inflammatory [70]. Oh et al. [71] demonstrated that hematein was efficacious in reducing the expression of VCAM-1 in the aorta of hypercholesterolemic New Zealand rabbits. Hematein also efficiently reduced TNF $\alpha$-induced VCAM- 1 expression in HUVECs [72]. Hematein diminished the increase in VCAM- 1 and MCP-1 levels induced by TNF $\alpha$ and oxidised LDL in HUVECs, respectively, as well as reducing TNF $\alpha$ and IL- $1 \beta$ production by peritoneal macrophages stimulated with LPS plus IFN $\gamma$. Furthermore, hematein also reduced the cell surface expression of adhesion molecules, resulting in the inhibition of THP-1 monocyte adhesion to TNF $\alpha$ stimulated HUVECs [73].

\section{Lignans}

Cho et al. [74] reported that 10 lignan constituents isolated from the rhizomes of Coptis japonica Makino (Ranunculaceae) including pinoresinol (21), woorenoside $\mathrm{V}(\mathbf{2 2})$ and lariciresinol glycoside had significant inhibitory effects on the TNF $\alpha$ production by LPS-activated RAW 264.7 cells. Five other dihydrobenzofuran neolignans, woorenosides (I-V), obtained from Coptis japonica Makino (Ranunculaceae), concentration-dependently blocked TNF $\alpha$ production by LPS-stimulated RAW 264.7 macrophages (IC $\mathrm{I}_{50}$ ranging from 15 to $60 \mu \mathrm{M}$ ) [75]. Other studies have demonstrated that some lignans, including savinin $\left(\mathrm{IC}_{50}=31.9 \mu \mathrm{M}\right)$ and calocedrin (23) $\left(\mathrm{IC}_{50}>150 \mu \mathrm{M}\right)$ isolated from the heartwood of Pterocarpus santalinus Makino (Leguminosae) [76], or pinoresi- 
<smiles>COc1cc(C2OCC3C(c4ccc(O)c(OC)c4)OCC23)ccc1O</smiles><smiles>[R7]OC/C=C/c1cc(OC)c2c(c1)C(CO)[C@H](c1ccc(O)c(OC)c1)O2</smiles>

(22) woorenoside $V$<smiles>O=C1O[C@H](O)[C@@H](CC2=CC3OC[C@H](O3)[C@@H]2O)/C1=C\c1ccc2c(c1)OCO2</smiles>

nol, woorenoside $\mathrm{V}$ and lariciresinol glycoside $\left(\mathrm{IC}_{50}\right.$ values between 50 and $100 \mu \mathrm{M}$ ) obtained from rhizomes of Coptis japonica Makino [76], caused a significant inhibition of $\operatorname{TNF} \alpha$ production in RAW 264.7 macrophages stimulated with LPS. In addition, the same lignans from Pterocarpus santalinus Makino (Leguminosae) also inhibited the T-cell proliferation elicited by concanavalin A, without displaying cytotoxic effects [77]. The sesquineolignans, named morinols $\mathrm{A}$ and $\mathrm{B}$, isolated from the roots of the Chinese medicinal herb Morina chinensis P.Y. Pai (Dipsacaceae) produced a significant inhibition of cytokines formation, including TNF $\alpha$, IL-4, IL-2 and IFN- $\gamma$ in human peripheral blood mononuclear cells. However, morinol B $\left(\mathrm{IC}_{50}>10 \mu \mathrm{g} / \mathrm{mL}\right)$ exhibited a more pronounced activity than its isomer, morinol A [78]. Interestingly, recent data indicate that LPS-treated mice fed a sesamol diet showed a reduction in IL-6 levels in the plasma [79]. Likewise, LPS-treated rats fed with a sesamin-supplemented diet presented reduced TNF $\alpha$ levels in the plasma [80]. Finally, six lignans isolated from Magnoliae fargesii Cheng (Magnoliaceae) produced a marked inhibition of the expression of ICAM-1 and VCAM- 1 on the surface of THP- 1 human monocytes ( IC $_{50}$ values between 20 and $60 \mu \mathrm{M}$ ) [81].

\section{Terpenes}

Recently, it has been reported that an extract of Tripterygium wilfordii Hook F (Celastraceae) markedly inhibited mRNA synthesis and protein expression of MMP-3 and MMP-13, induced by the pro-inflammatory cytokines IL- $1 \beta$, IL-17 and TNF $\alpha$ as assessed in primary osteoarthritic human or normal bovine chondrocytes $\left(\mathrm{IC}_{50}>5 \mathrm{ng} / \mathrm{mL}\right.$ ) [82]. The authors have suggested that the extract of $T$. wilfordii could be useful as a source and template for novel antiarthritic and cartilage-protective drugs [82]. In addition, celastrol (24) ( IC $_{50}$ values between 30 and $100 \mathrm{nM}$ ) decreased the production of the pro-inflammatory cytokines TNF $\alpha$ and IL-1 $\beta$ in human monocytes and macrophages. Celastrol ( $3 \mathrm{mg} / \mathrm{kg}$ ) has also been reported to inhibit rat adjuvant-induced arthritis, thus confirming its reported in vitro anti-inflammatory

properties. It has been proposed that celastrol might be useful for improving performance in memory, learning and psychomotor activities, and common features of the neurodegenerative diseases accompanied by inflammation, such as Alzheimer's disease [83]. In addition, it was demonstrated that structurally different sesquiterpene lactones, which possess an $\alpha$-methylene- $\gamma$ lactone function and a conjugated carbonyl group, reduced the production of IL- $1 \beta$, TNF $\alpha$ and IL- 6 in adherent mouse peritoneal exudate cells in a concentration-dependent manner $\left(\mathrm{IC}_{50}\right.$ ranging between 0.69 and $1.70 \mu \mathrm{M}$ ) [84]. Schnyder et al. [85] have reported that parthenolide (25) $\left(\mathrm{IC}_{50}<10 \mu \mathrm{M}\right)$ blocked the VCAM-1 expression induced by IL- 4 in endothelial cells. It was recently shown that parthenolide and the other terpenic compounds isolantolactone and alantolactone decreased the expression of IL-2 in T-lymphocytes [86].

It has been recently reported that ginsenosides Rb1 (26) and Rb2 (27), the major constituents of Panax ginseng C.A. Meyer (Araliaceae), are effective in inhibiting TNF $\alpha$ production in RAW 264.7 and U937 cells stimulated with LPS. The mean $\mathrm{IC}_{50}$ values observed were 56.5 and $51.3 \mu \mathrm{M}$ for Rb1 and 27.5 and $26.8 \mu \mathrm{M}$ for $\mathrm{Rb} 2$, in RAW264.7 and U937 cells, respectively [87]. The inhibitory activity of $\mathrm{Rb} 1$ and $\mathrm{Rb} 2$ was significantly increased by inhibitors of protein kinase $\mathrm{C}$ and $\mathrm{A}$, protein tyrosine kinase or by drugs used for the treatment of arthritis (chloroquine and steroid drugs), but not by AMP phosphodiesterase inhibitors. The authors suggested that ginsenosides could be of clinical interest for the management of TNF $\alpha$-mediated diseases, such as arthritis [87].

The terpenic saponin kalopanaxsaponin A (28) (approximate $\mathrm{IC}_{50}$ value $5 \mu \mathrm{M}$ ) isolated from Kalopanax pictus Nakai (Araliaceae) prevented the formation of TNF $\alpha$ by RAW 264.7 macrophages stimulated with LPS at concentrations up to $5 \mu \mathrm{M}$ [88]. Huang et al. [89] reported that tripterine (29) isolated from Tripterygium
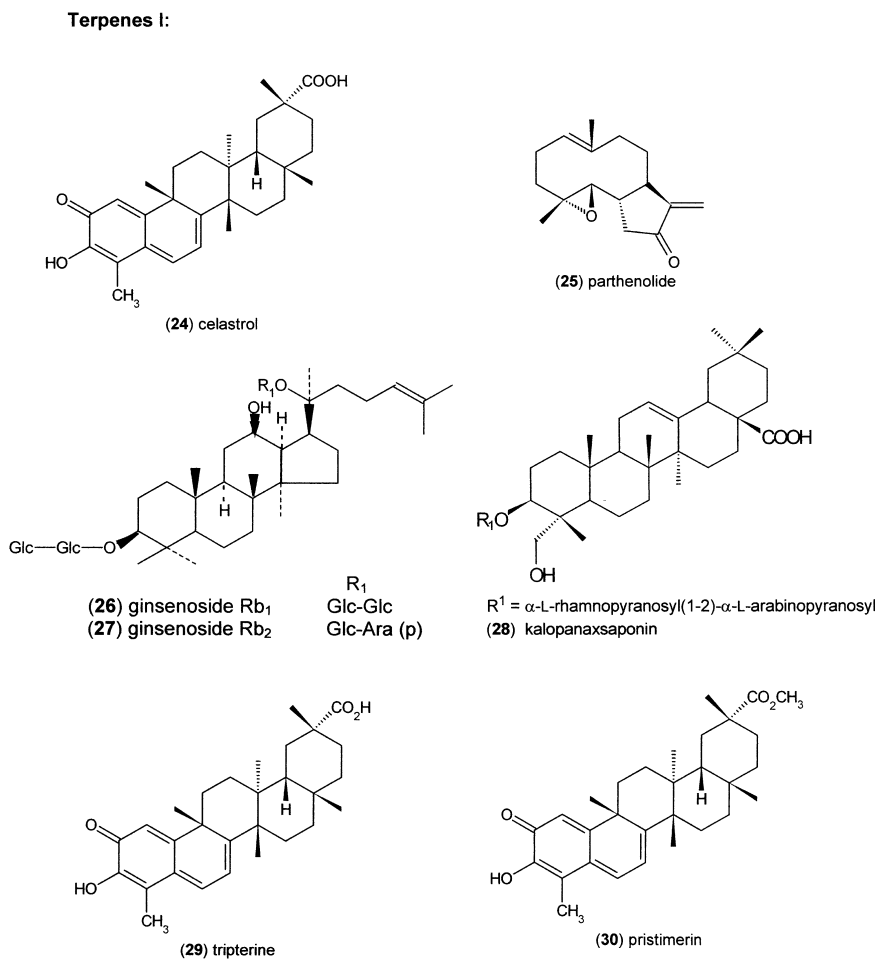
wilfordii Hook F. (Celastraceae), or pristimerin (30) and tingenone (31) isolated from Maytenus canariensis Kunk et Sund (Celastraceae) inhibited LPS-stimulated IL-1 $\beta$ production on human monocytes, with mean $\mathrm{IC}_{50}$ values of 40,56 and $58 \mathrm{nM}$. In addition, several sesquiterpene pyridine alkaloids of $T$. wilfordii, named wilfornines A, B and C, as well as several other related compounds, showed significant inhibitory effects on the production of a range of pro-inflammatory cytokines, including TNF $\alpha$, IL-1 $\beta$, IL-4, IL- 2 and IFN- $\gamma$ in human peripheral mononuclear cells (when assessed in the concentration of $10 \mu \mathrm{g} / \mathrm{mL}$ ) [90]. Other sesquiterpene lactones including cynaropicrin (32), reynosin (33) and santamarine (34) from roots of Saussurea lappa Radix (Compositae) inhibited TNF $\alpha$ production in LPS-activated RAW 264.7 cells, with IC $_{50}$ values of $8.2 \mu \mathrm{M}$ for cynaropicrin, $87.4 \mu \mathrm{M}$ for reynosin and $105 \mu \mathrm{M}$ for santamarine [91]. Furthermore, treatment with sulphydryl (thiol, $-\mathrm{SH}$ ) compounds such as L-cysteine, dithiothreitol, and 2-mercaptoethanol abrogated the inhibitory effect of cynaropicrin on TNF $\alpha$ production. The authors have proposed that the main inhibitory component of Saussurea lappa Radix is cynaropicrin and that its action seems to be mediated through conjugation with SH-groups of target proteins [91].

Jung et al. [92] reported that reynosin $\left(\mathrm{IC}_{50}=1 \mu \mathrm{M}\right)$ exhibited a concentration-dependent inhibition of CINC-1 formation in NRK-52E rat kidney epithelial cells stimulated with LPS. Moreover, the diterpenes casearinols A and B and casearinones A and B isolated from Casearia guianensis J. R. Johnston (Flacourtiaceae) were found to be effective in reducing the expression of ICAM-1 and VCAM-1 in THP-1 human monocytes [93]. Terpinen-4-ol, the main constituent of the essential oil of Melaleuca alternifolia (Maiden and Betche) Cheel (Myrtaceae) (tea tree oil) suppressed the formation of TNF $\alpha$, IL-1 $\beta$, IL-8, IL-10 according to an assessment in LPS-activated human peripheral blood monocytes [94].

\section{Terpenes II:}
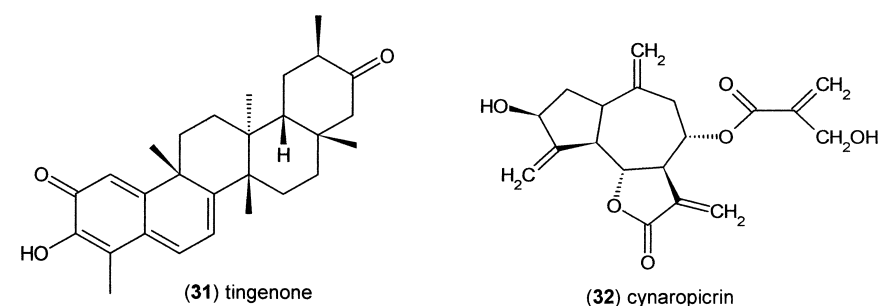

(32) cynaropicrin

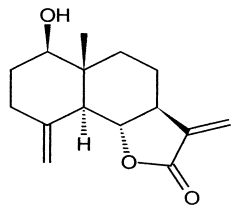

(33) reynosin

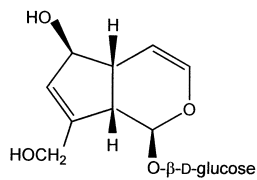

(35) aucubin

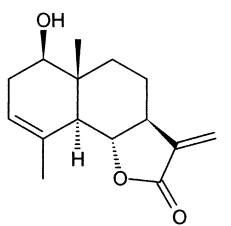

(34) santamarine

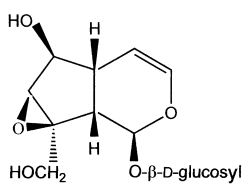

(36) catalpol
The iridoid glycosides, such as aucubin (35), catalpol (36), swetiamarin and gardenoside represent a group of cyclopentano[c]pyran monoterpenoids and have been found as constituents of several oriental medicine plants. Aucubin prevented TNF $\alpha$ and IL-6 production in RBL-2H3 stimulated mast cells ( IC $_{50}$ values of 101 and $190 \mathrm{ng} / \mathrm{mL}$, respectively), through a mechanism involving the blockade of NF- $\kappa \mathrm{B}$ activation [95]. Catalposide, the major iridoid glycoside obtained from the stem bark of Catalpa ovata G. Don (Bignoniaceae) was effective in preventing the production of TNF $\alpha$, IL-1 $\beta$ and IL-6 in LPS-activated macrophages, possibly via $\mathrm{NF}-\kappa \mathrm{B}$ inhibition (approximate $\mathrm{IC}_{50}$ value of $50 \mathrm{ng} /$ $\mathrm{mL}$ ) [96].

Interestingly, the oral administration of cannabinoids has been proposed for the treatment of multiple sclerosis, since cannabinoids seem to stimulate lymphocytes in the CNS by increasing the levels of TNF $\alpha$ [97]. These results are still not conclusive, but open new possibilities for the employment of cannabinoids to treat multiple sclerosis.

\section{Other Compounds}

Physalin B, a seco-steroid isolated from Physalis angulata L. (Solanaceae) produced a marked inhibition of the generation of TNF $\alpha$, IL-6 and IL-12 in macrophages stimulated with LPS and IFN $\gamma\left(\right.$ IC $\left._{50}<2 \mu \mathrm{g} / \mathrm{mL}\right)$. Physalin B $(0.5 \mathrm{mg} /$ mouse $)$ also reduced the levels of TNF $\alpha$ in the serum of LPS-treated mice. Nevertheless, physalin B was effective in preventing the septic shock induced by LPS in mice [98].

Shikonin (37) was reported to be a component of the traditional Chinese herbal medicine, Lithospermum erythrorhizon Sieb. and Zucc. (Boraginaceae), which possesses anti-inflammatory activities [99]. Shikonin blocked the binding of RANTES (regulated upon activation on normal T-cell expressed and secreted) and MIP- $1 \alpha$, but not SDF- $1 \alpha$ to human monocytes ( IC $_{50}$ values of 3.6 and $2.6 \mu \mathrm{M}$, respectively) [100]. Shikonin also blocked RANTES and MIP- $1 \alpha$ binding to human embryonic kidney (HEK)/293 cells transfected with the stable CC chemokine receptor- 1 (CCR1) ( IC $_{50}$ values of 2.63 and $2.57 \mu \mathrm{M}$ ). Furthermore, shikonin inhibited RANTES-induced CCR1 cell migration, without interfering with CCR1 cell migration induced by epidermal growth factor (EGF). The authors suggest that shikonin appears to be a highly specific antagonist for the CCR1 receptor and holds promise for the future design of more potent, highly selective therapeutics for the treatment of inflammatory autoimmune diseases [100].

Another study has indicated that the specially processed extract of radix Stephaniae tetrandrae S. Moore (Menispermaceae) (containing $1.3 \%$ of tetrandrine and $0.7 \%$ of fangchinoline) and the main alkaloids tetrandrine (38) and fangchinoline (39) prevented integrin-mediated neutrophil adhesion and transmigration induced by fMLP or leukotriene $\mathrm{B}_{4}$ ( $\mathrm{IC}_{50}$ values between 1 to $5 \mu \mathrm{g} / \mathrm{mL}$ ) [101]. Tetrandrine and fangchinoline also showed a marked inhibitory effect on IL-6 activity in vitro $\left(\right.$ IC $_{50}>6 \mu \mathrm{M}$ ) [102]. These two compounds also reduced the increase of IL- $\beta$ and $\mathrm{TNF} \alpha$ levels in human peripheral blood mononuclear cells stimulated with Staphylococcus aureus Cowan-1 [103]. Colchicine (40) from Colchicum autumnale L. (Colchicaceae) presented 
Jther Compounds:
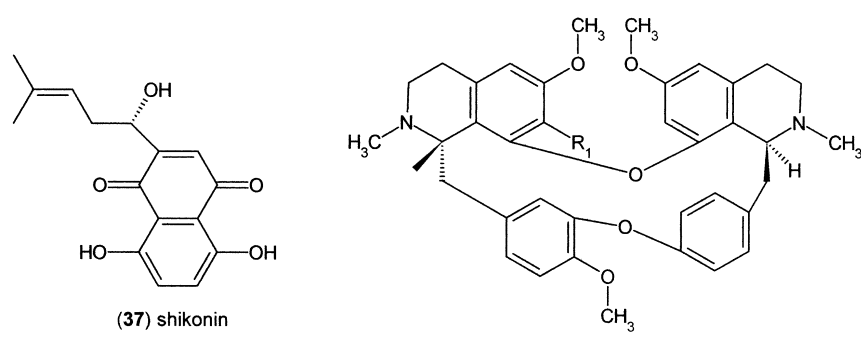

$\begin{array}{lc}\text { (38) tetrandrine } & \mathrm{R}_{1} \\ \text { (39) fangchinoline } & \mathrm{CH}_{3} \\ \mathrm{OCH}_{3}\end{array}$<smiles>COc1cc2c(c(OC)c1OC)-c1ccc(OC)c(=O)cc1[C@@H](NC(C)=O)CC2</smiles>

(40) colchicine

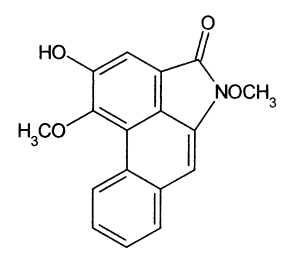

(41) piperlactam $\mathrm{S}$

a significant inhibitory effect on the induction of VCAM- 1 in both TNF $\alpha$ - and IL- $1 \beta$-stimulated HUVECs [104]. Colchicine was also found to be effective in reducing the levels of IL-6, TNF $\alpha$ and IL-8 in the serum of patients with familial Mediterranean fever after 2 months of treatment [105]. Likewise, colchicine downregulated the expression of ICAM- 1 and selectin on the surface of HUVECs [106].

The alkaloid piperlactam S (41) isolated from Piper kadsura (Choisy) Ohwi (Piperaceae) inhibited C5a-induced release of TNF $\alpha$ and IL-1 $\beta$ in RAW 264.7 macrophages [107]. Finally, very recently Yesilada et al. [108] reported that 55 extracts or fractions obtained from 10 plant species used in Turkish folk medicine for the treatment of rheumatism and related inflammatory diseases, showed inhibitory effects on the production of IL- $1 \alpha /$ IL$1 \beta$ and TNF $\alpha$ by human peripheral mononuclear cells stimulated with LPS [108].

\section{Conclusion}

Recent data from the literature demonstrate that plenty plantderived compounds present important anti-inflammatory activities and most of their actions are related to their ability to inhibit cytokine, chemokine or adhesion molecule synthesis and/or action. As discussed before, many inflammatory disorders including sepsis, rheumatoid arthritis and asthma are intimately associated with an imbalance of the cytokine network, as well as to an exaggerated cell influx to the sites of inflammation. In fact, the pharmaceutical industries are currently making tremendous efforts in order to identify new, relevant therapeutic molecules capable of modulating cytokine- and chemokineactivated responses. These agents would be useful not only for the treatment of inflammatory disorders, but also for the control of some other diseases which present an inflammatory origin, such as atherosclerosis and Alzheimer's disease. Although some cytokine modulators, for instance, selective blockers of IL- $1 \beta$ and TNF $\alpha$ receptors, have been employed clinically, the use of these drugs presents some disadvantages, especially regarding their high cost, important side effects and route of administration (effective therapy requires at least 2 subcutaneous injections a week). In this context, the development of therapeutic agents based on plant-derived compounds that present anti-cytokine activities would have clear benefits. Thus, plant-derived agents could be used alone or in association with other available antiinflammatory drugs, allowing a reduction in costs and/or side effects and possibly leading to an increase in effectiveness. However, most of the anti-inflammatory studies on plant-derived compounds have been carried out in vitro, and in vivo experiments would be required to confirm their efficacy. Furthermore, only a few plant-derived compounds have been submitted to clinical trials to test their potential as anti-inflammatory agents. Finally, as most of the anti-inflammatory compounds are found in several vegetable plant species, it is tempting to suggest that many other plants, not used in folk medicine to treat inflammatory diseases, could present anti-inflammatory properties. Thus, as cytokines are critically involved in most relevant and untreatable inflammatory diseases, large scale studies with plant-derived compounds would constitute a very attractive and relevant field to identify new, effective anti-inflammatory drugs.

\section{References}

1 Sacca R, Cuff CA, Ruddle NH. Mediators of inflammation. Current Opinion in Immunology 1997; 9: 851 - 7

2 Barnes PJ. Cytokine modulators as novel therapies for asthma. Annual Review in Pharmacology and Toxicology 2002; 42: 81-98

3 Haddad JJ. Cytokines and related receptor-mediated signaling pathways. Biochemical and Biophysical Communications 2002; 297 : $700-13$

${ }^{4}$ Hopkins SJ. The pathophysiological role of cytokines. Legal Medicine 2003; 5: S45-57

5 Dinarello CA. Pro-inflammatory cytokines. Chest 2000; 118: $503-8$

6 Opal SM, DePalo VA. Anti-inflammatory cytokines. Chest 2000; 117: $1162-72$

7 Kracht M, Saklatvala J. Transcriptional and post-transcriptional control of gene expression in inflammation. Cytokine 2002; 20: 91 - 106

8 Barnes PJ, Karin M. Nuclear factor- $\kappa \mathrm{B}$ - a pivotal transcription factor in chronic inflammatory diseases. The New England Journal of Medicine 1997; 336: $1006-71$

9 Donaldson LF, Hanley MR, Villabalnca AC. Inducible receptors. Trends in Pharamcological Sciences 1997; 18: 171-81

10 Luster AD. Chemokines - chemotatic cytokines that mediate inflammation. New England Journal of Medicine 1998; 338: 436-45

11 Wong MM, Fish EN. Chemokines: attractive mediators of the immune response. Seminars in Immunology 2003; 15: 5 - 14

12 D'Ambrosio D, Panina-Bordignon P, Sinigaglia F. Chemokine receptors in inflammation: an overview. Journal of Immunological Methods 2003; $273: 3-13$

13 Feldmann M, Brennan FM, Maini R. Cytokines in autoimmune disorders. Internal Review in Immunology 1998; 17: 217-28

14 Proudfoot AEI, Power CA, Rommel C, Wells TNC. Strategies for chemokine antagonists as therapeutics. Seminars in Immunology 2003; 15: $57-65$

15 Young PR. Pharmacological modulation of cytokine action and production through signaling pathways. Cytokine \& Growth Factor Reviews 1998; 9: 239-57

16 Andreakos ET, Foxwell BM, Brennan FM, Maini RN, Feldmann M. Cytokinies and anti-cytokine biologicals in autoimmunity: present and future. Cytokine \& Growth Factor Reviews 2002; 13: 299-313

17 Feldmann M. Development of anti-TNF therapy for rheumatoid arthritis. Nature Review Immunology 2002; 2: 364 - 71

18 Habtemariam S. Natural inhibitors of tumor necrosis factor- $\alpha$ production, secretion and function. Planta Medica 2000; 66: 303-13 
19 Gerritsen ME, Carley WW, Ranges GE, Shen CP, Phan SA, Ligon GF, Perry CA. Flavonoids inhibit cytokine-induced endothelial cell adhesion protein gene expression. American Journal of Pathology 1995: 147: $278-92$

20 Middleton E Jr. Effect of plant flavonoids on immune and inflammatory cell function. Advance Experimental Medicine and Biology 1998; 439: $175-82$

21 Di Carlo G, Mascolo N, Izzo AA, Capasso F. Flavonoids: old and new aspects of a class of natural therapeutic drugs. Life Sciences 1999; 65: $337-53$

22 Xagorari A, Papapetropoulos A, Mauromatis A, Economou M, Fotsis T, Roussos C. Luteolin inhibits an endotoxin-stimulated phosphorylation cascade and proinflammatory cytokine production in macrophages. The Journal of Pharmacology and Experimental Therapeutics 2001; 296: $181-7$

23 Ueda H, Yamazaki C, Yamazaki M. Luteolin as an anti-inflammatory and anti-allergic constituent of Perilla frutescens. Biological \& Pharmaceutical Bulletin 2002; 25: 1197-202

24 Kotanidou A, Xagorari A, Bagli E, Kitsanta P, Fotsis T, Papapetropoulos A, Roussos C. Luteolin reduces lipopolysaccharide-induced letha toxicity and expression of proinflammatory molecules in mice. American Journal of Respiratory Critical Care in Medicine 2002; 1165 $818-23$

25 Das M, Ram A, Ghosh B. Luteolin alleviates bronchoconstriction and airway hyperreactivity in ovalbumin sensitized mice. Inflammation Research 2003; 52: $101-6$

26 Manna SK, Mukhopadhyay A, Van NT, Aggrawal BB. Silymarin suppresses TNF-induced activation of NF- $\kappa B$, c-Jun N-terminal kinase, and apoptosis. The Journal of Immunology 1999; 163: 6800-9

27 Johnson VJ, Osuchowski MF, He Q, Sharma RP. Physiological responses to a natural antioxidant flavonoid mixture, silymarin, in BALB/c mice: II. Alterations in thymic differentiation correlate with changes in c-myc gene expression. Planta Medica 2002; 68: 961 - 5

28 Ishiwa J, Sato T, Mimaki Y, Sashida Y, Yano M, Ito A. A citrus flavonoid, nobiletin, suppresses production and gene expression of matrix metalloproteinase 9/gelatinase B in rabbit synovial fibroblasts. Journal of Rheumatology 2000; 27: 20-5

29 Lin N, Sato T, Takayama Y, Mimaki Y, Sashida Y, Yano M, Ito A. Novel anti-inflammatory actions of nobiletin, a citrus polymethoxy flavonoid, on human synovial fibroblasts and mouse macrophages. Biochemical Pharmacology 2003; 65: 2065-71

30 Kubo M, Matsuda H, Tanaka M, Kimura Y, Okuda H, Higashino M, Tani T, Namba K, Arichi S. Studies on Scutellariae radix: VII. Anti-arthritic and anti-inflammatory actions of methanolic extract and flavonoids components from Scutellariae radix. Chemistry Pharmacology Bulletin 1984; 32: $2724-9$

31 Chen Y-C, Shen S-C, Chen L-G, Lee T J-F, Yang L-L. Wogonin, baicalin, and baicalein inhibition of inducible nitric oxide synthase and cyclooxygenase-2 gene expressions induced by nitric oxide synthase inhibitors and lipopolysaccharide. Biochemical Pharmacology 2001, 61: $1417-27$

32 Chiu JH, Lay IS, Su MY, Chiu HL, Chiu SN, Lui WY, Wu CW. Tumor necrosis factor-producing activity of wogonin in RAW 264.7 murine macrophage cell line. Planta Medica 2002; 68: 1036-9

33 Li BQ, Fu T, Gong W-H, Dunlop N, Kung H-F, Yan Y, Kang J, Wang JM. The flavonoids baicalin exhibits anti-inflammatory activity by binding to chemokines. Immunopharmacology 2000; 49: 295306

34 Nakajima T, Imanishi M, Yamamoto K, Cyong JC, Hirai K. Inhibitory effect of baicalein, a flavonoid in Scutellaria Root, on eotaxin production by human dermal fibroblasts. Planta Medica 2001; 67: $32-5$

35 Kimura Y, Matsushita N, Yokoi-Hayashi K, Okuda H. Effects of baicalein isolated from Scutellaria baicalensis on adhesion molecule expression induced by thrombin and thrombin receptor agonist peptide in cultured human umbilical vein endothelial cells. Planta Medica 2001; 67: $331-4$

36 Sartor L, Pezzato E, Dell'Aica I, Caniato R, Biggin S, Garbisa S. Inhibition of matrix-proteases by polyphenols: chemical insights for antiinflammatory and anti-invasion drug design. Biochemical Pharmacology 2002; 64: 229-37

37 Krakauer T, Li BQ, Young HA. The flavonoid baicalin inhibits superantigen-induced inflammatory cytokines and chemokines. FEBS Letters 2001; 500: $52-5$
38 Shen YC, Chiou WF, Chou YC, Chen CF. Mechanisms in mediating the anti-inflammatory effects of baicalin and baicalein in human leukocytes. European Journal of Pharmacology 2003; 465: 171 - 81

39 Nakamura N, Hayasaka S, Zhang XY, Nagaki Y, Matsumoto M, Hayasaka Y, Terasawa K. Effects of baicalin, baicalein, and wogonin on interleukin-6 and interleukin-8 expression, and nuclear factor-kappa B binding activities induced by interleukin-1beta in human retinal pigment epithelial cell line. Experimental Eye Research 2003; 77: 195202

40 Wadsworth TL, McDonald TL, Koop DR. Effects of Ginkgo biloba extract (EGb 761) and quercetin on lipopolysaccharide-induced signaling pathways involved in the release of tumor necrosis factor- $\alpha$. Biochemical Pharmacology 2001; 62: $963-74$

41 Manjeet KR, Ghosh B. Quercetin inhibits LPS-induced nitric oxide and tumor necrosis factor- $\alpha$ production in murine macrophages. International Journal of Immunopharmacology 1999; 21: 435-43

42 Wei BL, Lu CM, Tsao LT, Wang JP, Lin CN. In vitro anti-inflammatory effects of quercetin 3-O-methyl ether and other constituents from Rhamnus species. Planta Medica 2001; 67: 745-47

43 Cho JY, Kim PS, Park J, Yoo ES, Baik KU, Kim YK, Park MH. Inhibitor of tumor necrosis factor-alpha production in lipopolysaccharide-stimulated RAW264.7 cells from Amorpha fruticosa. Journal of Ethnopharmacology 2000; 70: 127-33

44 Park KY, Lee SH, Min BK, Lee KS, Choi JS, Chung SR, Min KR, Kim Y. Inhibitory effect of luteolin 4'-O-glucoside from Kummerowia striato and other flavonoids on interleukin-5 bioactivity. Planta Medica 1999; 65: 457-9

45 Okabe S, Suganuma M, Imayoshi Y, Taniguchi S, Yoshida T, Fujiki H. New TNF $\alpha$ releasing inhibitors, geraniin and corilagin, in leaves of Acer nikoense, Megusurino-Ki. Biological \& Pharmaceutical Bulletin 2001; $10: 1145-8$

46 Jang MK, Sohn DH, Ryu JH. A curcuminoid and sesquiterpenes as inhibitors of macrophage TNF-alpha release from Curcuma zedoaria. Planta Medica 2001; 67: 550-2

47 Kang BY, Chung SW, Kim TS. Inhibition of interleukin-12 production in lipopolysaccharide-activated mouse macrophages by hypericin, an active component of Hypericum perforatum. Planta Medica 2001; 67: $364-6$

48 Bork PM, Bacher S, Schimitz ML, Kaspers U, Heinrich M. Hypericin as a non-antioxidant inhibitor of NF-kappa B. Planta Medica 1999; 65: 297-300

49 Oh GS, Pae HO, Choi BM, Jeong S, Oh H, Oh CS, Rho YD, Kim DH, Shin MK, Chung HT. Inhibitory effects of the root cortex of Paeonia suffruticosa on interleukin-8 and macrophage chemoattractant protein-1 secretions in U937 cells. Journal of Ethnopharmacology 2003; 84: $85-9$

50 Chou TC. Anti-inflammatory and analgesic effects of paeonol in carrageenan-evoked thermal hyperalgesia. British Journal of Pharmacology 2003; 139: $1146-52$

51 Cho KJ, Yun CH, Packer L, Chung AS. Inhibition mechanisms of bioflavonoids extracted from the bark of Pinus maritima on the expression of proinflammatory cytokines. Annals of the New York Academy of Science 2001; 928: 141 - 56

52 Bito T, Roy S, Sen CK, Shirakawa T, Gotoh A, Ueda M, Ichihashi M, Packer L. Flavonoids differentially regulate IFN- $\gamma$-induced ICAM- 1 expression in human keratinocytes: molecular mechanisms of action. FEBS Letters 2002; 520: 145-52

53 Manthey JA, Grohmann K, Montanari A, Ash K, Manthey CL. Polymethoxylated flavones derived from Citrus suppress tumor necrosis factor- $\alpha$ expression by human monocytes. Journal Natural Products 1999; 62: $441-4$

54 Hunter MS, Corley DG, Carron CP, Rowold E, Kilpatrick BF, Durley RC Four new clerodane diterpenes from the leaves of Casearia guianensis which inhibit the interaction of leukocyte function antigen 1 with intercellular adhesion molecule 1. Journal Natural Products 1997; 60: 894-99

55 Ahn KS, Kim JH, Oh SR, Ryu SY, Lee HK. Inhibitory activity of stilbenes from medicinal plants on the expression of cell adhesion molecules on THP1 cells. Planta Medica 2000; 66: $641-4$

56 Tanaka S, Sakata Y, Morimoto K, Tambe Y, Watanabe Y, Honda G, Tabata M, Oshima T, Masuda T, Umezawa T, Shimada M, Nagakura N, Kamisako W, Kashiwada Y, Ikeshiro Y. Influence of natural and synthetic compounds on cell surface expression of cell adhesion molecules, ICAM-1 and VCAM-1. Planta Medica 2001; 67: 108-13 
57 Yamazaki R, Hatano H, Aiyama R, Matsuzaki T, Hashimoto S, Yokokura T. Diarylheptanoids suppress expression of leukocyte adhesion molecules on human vascular endothelial cells. European Journal of Pharmacology 2000; 404: 375-85

58 Ashikawa K, Majumdar S, Banerjee S, Bharti AC, Shishodia S, Aggarwal BB. Piceatannol inhibits TNF-induced NF-kappaB activation and NFkappaB-mediated gene expression through suppression of IkappaBalpha kinase and p65 phosphorylation. The Journal of Immunology 2002; 169: $6490-7$

59 Krakauer T. The polyphenol chlorogenic acid inhibits staphylococcal exotoxin-induced inflammatory cytokines and chemokines. Immunopharmacology and Immunotoxicology 2002; 24: 113-9

60 Jung JH, Ha JY, Min KR, Shibata F, Nakagawa H, Kang SS, Chang IM, Kim Y. Reynosin from Sassurea lappa as inhibitor on CINC-1 induction in LPS-stimulated NRK-52E cells. Planta Medica 1998; 64: 54-5

61 Tsuda T, Horio F, Osawa T. Cyanidin 3-O-beta-D-glucoside suppresses nitric oxide production during a zymosan treatment in rats. Journal of Nutrition Sciences Vitaminol (Tokyo) 2002; 48: 305-10

62 Ishii R, Horie M, Saito K, Arisawa M, Kitanaka S. Inhibition of lipopolysaccharide-induced pro-inflammatory cytokine expression via suppression of nuclear factor-kappaB activation by Mallotus japonicus phloroglucinol derivatives. Biochimica et Biophysica Acta 2003; 1620: $108-18$

63 Calixto JB, Otuki MF, Santos ARS. Anti-inflammatory compounds of plant origin. Part I. Action on arachidonic acid pathway, nitric oxide and nuclear factor $\kappa \mathrm{B}(\mathrm{NF}-\kappa \mathrm{B})$. Planta Medica 2003; 69: 973-83

${ }^{64}$ Natarajan C, Bright JJ. Curcumin inhibits experimental allergic encephalomyelitis by blocking IL-12 signaling through Janus Kinase-STAT pathway in T lymphocytes. The Journal of Immunology 2002; 169 $6506-13$

65 Liacini A, Sylvester J, Qing Li W, Huang W, Dehnade F, Ahmad M, Zafarullah $M$. Induction of matrix metalloproteinase- 13 gene expression by TNF-alpha is mediated by MAP kinases, AP-1, and NF-kappaB transcription factors in articular chondrocytes. Experimental Cell Research 2003; 288: $208-17$

66 Banerjee M, Tripathi LM, Srivastava VM, Puri A, Shukla R. Modulation of inflammatory mediators by ibuprofen and curcumin treatment during chronic inflammation in rat. Immunopharmacology and Immunotoxicology 2003; 25: 213-24

67 Chainani-Wu N. Safety and anti-inflammatory activity of curcumin: a component of tumeric (Curcuma longa). The Journal of Alternative \& Complementary Medicine 2003; 9: 161-8

68 Cheng AL, Hsu CH, Lin JK, Hsu MM, Ho YF, Shen TS, Ko JY, Lin JT, Lin BR, Ming-Shiang W, Yu HS, Jee SH, Chen GS, Chen TM, Chen CA, Lai MK, Pu YS, Pan MH, Wang YJ, Tsai CC, Hsieh CY. Phase I clinical trial of curcumin, a chemopreventive agent, in patients with high-risk or premalignant lesions. Anticancer Research 2001; 21: 2895-900

69 Aggarwal BB, Kumar A, Bharti AC. Anticancer potential of curcumin: preclinical and clinical studies. Anticancer Research 2003; 23: 363 98

70 Oh SR, Kim DS, Lee IS, Jung KY, Lee JJ, Lee HK. Anticomplementary activity of constituents from the heartwood of Caesalpinia sappan. Planta Medica 1998; 64: 456-8

71 Oh GT, Choi JH, Hong JJ, Kim DY, Lee SB, Kim JR, Lee CH, Hyun BH, Oh SR, Bok SH, Jeong TS. Dietary hematein ameliorates fatty streak lesions in the rabbit by the possible mechanism of reducing VCAM-1 and MCP-1 expression. Atherosclerosis 2001; 159: 17-26

72 Hong JJ, Jeong TS, Choi JH, Park JH, Lee KY, Seo YJ, Oh SR, Oh GT. Hematein inhibits tumor necrotic factor-alpha-induced vascular cell adhesion molecule-1 and NF-kappaB-dependent gene expression in human vascular endothelial cells. Biochemical and Biophysical Research Communications 2001; 281: 1127-33

73 Choi JH, Jeong TS, Kim DY, Kim YM, Na HJ, Nam KH, Lee SB, Kim HC, Oh SR, Choi YK, Bok SH, Oh GT. Hematein inhibits atherosclerosis by inhibition of reactive oxygen generation and NF-kappaB-dependent inflammatory mediators in hyperlipidemic mice. Journal of Cardiovascular Pharmacology 2003; 42: 287-95

74 Cho JY, Park J, Yoo ES, Yoshikawa K, Baik KU, Lee J, Park MH. Inhibitory effect of lignans from the rhizomes of Coptis japonica var. dissecta on tumor necrosis factor-alpha production in lipopolysaccharide-stimulated RAW264.7 cells. Archive of Pharmacal Research 1998; 21: $12-6$

75 Cho JY, Baik KU, Yoo ES, Yoshikawa K, Park MH. In vitro anti-inflammatory effects of neolignan woorenosides from the rhizomes of Coptis japonica. Journal of Natural Products 2000; 63: 1205-9
76 Cho JY, Park J, Kim PS, Yoo ES, Baik KU, Park MH. Savinin, a lignan from Pterocarpus santalinus inhibits tumor necrosis factor-alpha production and T cell proliferation. Biological \& Pharmaceutical Bulletin 2001; 24: 167-71

77 Cho JY, Kim AR, Park MH. Lignans from the rhizomes of Coptis japonica differentially act as anti-inflammatory principles. Planta Medica 2001; 67: 312-6

78 Su B-N, Takaishi Y, Kusumi T. Morinols A-L, twelve novel sesquineolignans and neolignans with a new carbon skeleton from Morina chinensis. Tetrahedron 1999; 55: 14571-86

79 Chavali SR, Forse RA. Decreased production of interleukin- 6 and prostaglandin $E_{2}$ associated with inhibition of delta-5 desaturation of omega6 fatty acids in mice fed safflower oil diets supplemented with sesamol. Prostaglandins, Leukotrienes and Essential Fatty Acids 1999; 61: 347-52

80 Utsunomiya T, Chavali SR, Zhong WW, Forse RA. Effects of sesaminsupplemented dietary fat emulsions on the ex vivo production of lipopolysaccharide-induced prostanoids and tumor necrosis factor $\alpha$ in rats. The American Journal of Clinical Nutrition 2000; 72: $804-8$

81 Ahn KS, Jung KY, Kim JH, Oh SR, Lee HK. Inhibitory activity of lignan components from the flower buds of Magnoliae fargesii on the expression of cell adhesion molecules. Biological \& Pharmaceutical Bulletin $2001 ; 24: 1085-7$

82 Sylvester J, Liacini A, Li WQ Dehnade F, Zafarullah M. Tripterygium wilfordii Hook $\mathrm{F}$ extract suppresses proinflammatory cytokine-induced expression of matrix metalloproteinase genes in articular chondrocytes by inhibiting activating protein- 1 and nuclear factor$\kappa B$ activities. Molecular Pharmacology 2001; 59: 1196-205

83 Allison AC, Cacabelos R, Lombardi VRM, Álvarez XA, Vigo C. Celastrol, a potent antioxidant and anti-inflammatory drug, as a possible treatment for Alzheimer's disease. Progress Neuro-Psychopharmacology \& Biological Psychiatry 2001; 25: $1341-57$

84 Koch E, Klaas CA, Rungeler P, Castro V, Mora G, Vichnewski W, Merfort I. Inhibition of inflammatory cytokine production and lymphocyte proliferation by structurally different sesquiterpene lactones correlates with their effect on activation of NF-kappaB. Biochemical Pharmacology 2001; 62: 795-801

85 Schnyder B, Schnyder-Candrian S, Panski A, Bömmel H, Heim M, Duschl A, Moser R. Phytochemical inhibition of interleukin-4-activated Stat 6 and expression of VCAM-1. Biochemical and Biophysical Research Communications 2002; 292: $841-7$

86 Humar M, Garcia-Pineres AJ, Castro V, Merfort I. Effect of sesquiterpene lactones on the expression of the activation marker CD69 and of IL-2 in T-lymphocytes in whole blood. Biochemical Pharmacology 2003; 65: $1551-63$

87 Cho JY, Yoo ES, Baik KU, Park MH, Han BH. In vitro inhibitory effect of protopanaxadiol ginsenosides on tumor necrosis factor (TNF)-alpha production and its modulation by known TNF-alpha antagonists. Planta Medica 2001; 67: 13-8

88 Kim YK, Kim RG, Park SJ, Ha JH, Choi JW, Park HJ, Lee KT. In vitro antiinflammatory activity of kalopanaxsaponin A isolated from Kalopanax pictus in murine macrophage RAW 264.7 cells. Biological \& Pharmaceutical Bulletin 2002; 25: 72-6

89 Huang FC, Chan WK, Moriarty KJ, Zhang DC, Chang M, He W, Yu KT, Zilberstein A. Novel cytokine release inhibitors. Part I: triterpenes. Bioorganic \& Medical Chemistry Letters 1998; 8: 1883-6

90 Duan H, Takaishi Y, Momota H, Ohmoto Y, Taki T, Jia Y, Li D. Immunosuppressive sesquiterpene alkaloids from Tripterygium wilfordii. Journal of Natural Products 2001; 64: $582-7$

91 Cho JY, Park J, Yoo ES, Baik KU, Jung JH, Lee J, Park MH. Inhibitory effect of sesquiterpene lactones from Saussurea lappa on tumor necrosis factor-alpha production in murine macrophage-like cells. Planta Medica 1998; 64: 594-7

92 Jung JH, Ha JY, Min KR, Shibata F, Nakagawa H, Kang SS, Chang IM, Kim Y. Reynosin from Sassurea lappa as inhibitor on CINC-1 induction in LPS-stimulated NRK-52E cells. Planta Medica 1998; 64: 454-5

93 Hunter MS, Corley DG, Carron CP, Rowold E, Kilpatrick BF, Durley RC. Four new clerodane diterpenes from the leaves of Casearia guianensis which inhibit the interaction of leukocyte function antigen 1 with intercellular adhesion molecule 1 . Journal of Natural Products 1997; 60 : $894-9$ 
94 Hart PH, Brand C, Carson CF, Riley TV, Prager RH, Finlay-Jones JJ. Terpinen-4-ol, the main component of the essential oil of Malaleuca alternifolia (tea tree oil), suppresses inflammatory mediator production by activated human monocytes. Inflammation Research 2000; 49: $619-26$

95 Jeong HJ, Koo HN, Na HJ, Kim MS, Hong SH, Eom JW, Kim KS, Shin TY, Kim HM. Inhibition of TNF-alpha and IL-6 production by Aucubin through blockade of NF-kappaB activation RBL-2H3 mast cells. Cytokine 2002; 18: $252-9$

96 An SJ, Pae HO, Oh GS, Choi BM, Jeong S, Jang SI, Oh H, Kwon TO, Song CE, Chung HT. Inhibition of TNF-alpha, IL-1beta, and IL-6 productions and NF-kappa B activation in lipopolysaccharide-activated RAW 264.7 macrophages by catalposide, an iridoid glycoside isolated from Catalpa ovata G. Don (Bignoniaceae). International Immunopharmacology 2002; 2: $1173-81$

97 Killestein J, Hoogervorst EL, Reif M, Blauw B, Smits M, Uitdehaag BM, Nagelkerken L, Polman $\mathrm{CH}$. Immunomodulatory effects of orally administered cannabinoids in multiple sclerosis. Journal of Neuroimmunology 2003; 137: 140-3

98 Soares MB, Bellintani MC, Ribeiro IM, Tomassini TC, Ribeiro dos Santos R. Inhibition of macrophage activation and lipopolysaccaride-induced death by seco-steroids purified from Physalis angulata L. European Journal of Pharmacology 2003; 459: 107-12

99 Tanaka S, Tajima M, Tsukada M, Tabata M. A comparative study on anti-inflammatory activities of the enantiomers, shikonin and alkannin. Journal of Natural Products 1986; 49: 66-9

100 Chen X, Oppenheim J, Howard OMZ. Shikonin, a component of antiinflammatory Chinese herbal medicine, selectively blocks chemokines binding to CC chemokines receptor-1. International Immunopharmacology 2001; 1: 229-36

101 Shen Y-C, Chou C-J, Chiou W-F, Chen C-F. Anti-inflammatory effects of the partially purified extract of radix Stephanie tetrandrae: comparative studies of its active principles tetrandrine and fangchinoline on human polymorphonuclear leukocyte functions. Molecular Pharmacology 2001; 60: $1983-90$
102 Choi HS, Kim HS, Min KR, Kim Y, Lim HK, Chang YK, Chung MW. Antiinflammatory effects of fangchinoline and tetrandrine. Journal of Ethnopharmacology 2000; 69: 173 -9

103 Onai N, Tsunokawa Y, Suda M, Watanabe N, Nakamura K, Sugimoto Y, Kobayashi Y. Inhibitory effects of bisbenzylisoquinoline alkaloids on induction of proinflammatory cytokines, interleukin-1 and tumor necrosis factor-alpha. Planta Medica 1995; 61: 497 - 501

${ }^{104}$ Asahina A, Tada Y, Nakamura K, Tamaki K. Colchicine and griseofulvin inhibit VCAM-1 expression on human vascular endothelial cells evidence for the association of VCAM-1 expression with microtubules. Journal of Dermatological Science 2001; 25: 1 -9

105 Kiraz S, Ertenli I, Arici M, Calguneri M, Haznedaroglu I, Celik I, Pay S, Kirazli S. Effects of colchicine on inflammatory cytokines and selectins in familial Mediterranean fever. Clinical and Experimental Rheumatology 1998; 16: 721 - 4

106 Perico N, Ostermann D, Bontempeill M, Morigi M, Amuchastegui CS, Zoja C, Akalin E, Sayegh MH, Remuzzi G. Colchicine interferes with Lselectin and leukocyte function-associated antigen-1 expression on human $\mathrm{T}$ lymphocytes and inhibits $\mathrm{T}$ cell activation. Journal of the American Society of Nephrology 1996; 7: 594-601

107 Chiou WF, Peng CH, Chen CF, Chou CJ. Anti-inflammatory properties of piperlactam S: modulation of complement $5 a$-induced chemotaxis and inflammatory cytokines production in macrophages. Planta Medica 2003; 69: 9-14

108 Yesilada E, Üstün O, Sezik E, Takaishi Y, Ono Y, Honda G. Inhibitory effects of Turkish folk remedies on inflammatory cytokines: interleukin- $1 \alpha$, interleukin- $1 \beta$ and tumor necrosis factor $\alpha$. Journal of Ethnopharmacology 1997; 58: 59-73 